Int. J. Dev. Biol. 51: 221-228 (2007)

doi: $10.1387 / \mathrm{ijdb} .062215 \mathrm{sb}$

Original Article

\title{
Compartments in Scyphozoa
}

\author{
STEFAN BERKING* and KLAUS HERRMANN \\ Zoological Institute, University of Cologne, Germany
}

\begin{abstract}
Polyps of Scyphozoa have a cup-shaped body. At one end is the mouth opening surrounded by tentacles, at the other end is an attachment disc. The body wall consists of two tissue layers, the ectoderm and the endoderm, which are separated by an extracellular matrix, the mesoglea. The polyp's gastric cavity is subdivided by septa running from the apical end to the basal body end. The septa consist of two layers of endoderm and according to biology textbooks the number of septa is four. However, in rare circumstances Aurelia produces polyps with zero, two, six, or eight septa. We found that the number was always even. Therefore we propose that two types of endoderm exist, forming alternating stripes running from the oral body end to the aboral end. The stripes have some properties of developmental compartments. Where cells of different compartments meet, they form a septum. We also propose that the ectoderm is subdivided into compartments. The borders of the ectodermal and endodermal compartments are perpendicular to each other. Tentacles of the polyp and rhopalia (sense organs) of the ephyra (young medusa), respectively, develop at the border between two ectodermal compartments. The number can be even or odd. Rhopalia formation is particularly favored where two ectodermal and two endodermal compartments meet.
\end{abstract}

KEY WORDS: Cnidaria, polyp, medusa, pattern formation, mathematical model

\section{Introduction}

Among cnidarians a solitary polyp has a simple polar organization with a mouth/anus opening at one end and a basal disc at the other. A cnidarian medusa displays essentially the same organization. The body wall consists of two germ layers that are separated by an extracellular matrix called the mesoglea. However, although we are defining this matrix as a mesoglea, we do not mean that on its two sides cells of different germ layers exist. At certain sites two layers of ectodermal tissue (such as the marginal lobes in Scyphozoa and the velum in Hydrozoa) and two layers of endodermal tissue (septa), respectively, are each separated by a mesoglea. In Cnidaria, the number 4 is of particular importance: In Scyphozoa polyps the gastric cavity is cup-shaped and, according to textbooks, subdivided into four equal-size quadrants by four septa running from the oral pole to the aboral. A septum consists of two layers of endodermal tissue separated by a mesoglea. On the oral disc are four depressions, called peristomal pits, that mark the beginning of four muscular strands that travel through the mesoglea of the septa to reach the attachment disc. In Anthozoa the gastric cavity is also subdivided by septa. In Octocorallia the number is 8 , in Hexacorallia the number usually is a multiple of 6 . Polyps of Scyphozoa produce medusae by transversal fission. A young medusa, or ephyra, has 8 or 16 arms. Polyps of Hydrozoa and Cubozoa do not display septa in their gastric cavity, but generally the medusae have a tetraradial symmetry. Thus the questions are, (1) What causes the favored tetraradial symmetry in cnidarians? and (2) What causes septum formation?

Rees (1966) argued that cnidarians originated from a fertile actinula differing from the modern actinula larva only in its ability to reproduce itself. With the evolution of a quadrant stomach, all the essential features for the evolution of all three classes of cnidarians would be present. Thiel (1966) and Hand (1966) argued that a scyphozoan-polyp-like individual with four septa was the forerunner of both Scyphozoa and Anthozoa. In general, functional arguments are given for the evolution of septa and muscles within septa, such as that (1) polyps with a large diameter need additional surface in the gastric cavity for digesting and absorbing food and that (2) the placement of muscles within the septa allows the polyp body to contract if needed. Having muscles in the septa is argued to be much more advantageous to the animal than are muscles in the body wall and indeed, musculature is almost absent in the body wall of Scyphozoa and Anthozoa polyps. Clearly, these structures display positive adaptive features, but we can also ask, How is the formation of these

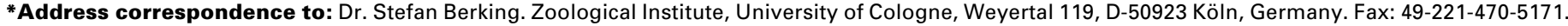
e-mail: s.berking@uni-koeln.de
} 
structures controlled?

To answer this question, we looked for deviations from the normal number of pattern elements, including tentacles, rhopalia, marginal arms and septa and we found several. They can be grouped: Some pattern elements are produced in both odd and even numbers, whereas others are only produced in even numbers. This difference indicates two different mechanisms of pattern control. In this study we concentrate on the Scyphozoon Aurelia aurita.

\section{Results}

On the number of septa and tentacles in polyps of Aurelia

In Aurelia aurita most polyps (Scyphistomae) have four septa (Figure 1A), but some were found to have two, six, or eight (Table 1, Fig. 1B, Fig. 2). The number of septa is not simply a matter of size; polyps with two or eight septa were found among the small as well as the large animals. Polyps produced by asexual reproduction in most cases had four septa, irrespective of the number of septa the parent animal had. In the course of several weeks,

\section{TABLE 1}

NUMBER OF POLYPS WITH $\boldsymbol{n}$ SEPTA IN A RANDOM SAMPLE OF AURELIA AURITA POLYPS

\begin{tabular}{lccccccr}
\hline $\boldsymbol{n}$ & 2 & 3 & 4 & 5 & 6 & 7 & 8 \\
$\begin{array}{l}\text { Number } \\
\text { of polyps }\end{array}$ & 10 & 0 & 209 & 0 & 19 & 0 & 2 \\
\hline
\end{tabular}

TABLE 2

\section{NUMBER OF SEPTA IN ASEXUALLY PRODUCED OFFSPRING OF AURELIA AURITA POLYPS}

\begin{tabular}{|c|c|c|c|c|}
\hline \multirow{2}{*}{$\begin{array}{l}\text { Initial number } \\
\text { of septa } \\
\text { of parent polyps }\end{array}$} & \multirow[t]{2}{*}{$\begin{array}{l}\text { Initial number } \\
\text { of polyps }\end{array}$} & \multicolumn{3}{|c|}{$\begin{array}{l}\text { Final number of polyps (parent and offspring) } \\
\text { with } n \text { septa }\end{array}$} \\
\hline & & $n=2$ & $n=4$ & $n=6$ \\
\hline 2 & 6 & 3 & 6 & 0 \\
\hline 4 & 92 & 2 & 116 & 2 \\
\hline 6 & 5 & 0 & 9 & 5 \\
\hline
\end{tabular}

some polyps with two septa developed two additional ones (Table 2). Rarely, polyps without septa develop. These polyps are thin and long. They are almost unable to contract, probably because retractor muscles, which are usually placed within the septa, are missing (Fig. 1E).

Polyps formed by asexual reproduction initially are small and generally have four septa, four gastric pouches and four tentacles. Then additional tentacles form, in particular midway between existing ones. In animals with four septa, the final number of tentacles is about 16 . Polyps with six septa produce about 8 tentacles more than those with four septa (Table 3). Apparently the number of pouches determines the final diameter of the ring in which tentacles form. In young polyps, the number of tentacles above a gastric pouch is highly variable. By counting a random sample of polyps of different size and age with four septa $(n=31)$, we found a mean per pouch of 2.0-2.81-2.84-3.03 tentacles. The sequence is determined in such a way that the pouch with the lowest number of tentacles is noted first and the number of tentacles above the pouches in clockwise direction is noted next. Due to an uncertainty of a correct classification the tentacle above or closest to a septum is omitted. The most extreme arrangements found are 1-2-3-7 and $0-1-1-3$ tentacles per pouch, respectively. The larger the pouch, the more tentacles are found related to it. Thus the result shows that initially the pouches can differ greatly in size and that the largest pouch is usually placed next to the smallest pouch $\left(\chi^{2}, p<0.05\right)$. In large polyps, the gastric pouches appear of almost equal size.

In summary, gastric pouches form in even numbers. Initially they vary in size. In the course of growth, the pouches enlarge until they are almost the same size. In the end, the number of pouches largely determines the diameter of the polyp at the position of the tentacle ring.

Influence of the number of septa in polyps on the number of various pattern elements of the resulting young medusae (ephyrae)

Polyps of Aurelia aurita produce medusae, initially termed ephyrae, by transverse fission (strobilation) (Figure 1C). Ephyrae usually have eight arms. In the center of each arm a sense organ,

TABLE 3

NUMBER OF TENTACLES IN LARGE POLYPS OF AURELIA AURITA

\begin{tabular}{|c|c|c|c|c|c|c|c|c|c|c|c|c|}
\hline Number of septa of polyps & & & & umber & lyps wi & re than & ntacles & two rar & n sample & & & \\
\hline & $n=16$ & $n=17$ & $n=18$ & $n=19$ & $n=20$ & $n=21$ & $n=22$ & $n=23$ & $n=24$ & $n=25$ & $n=26$ & $n=27$ \\
\hline 4 & 18 & 8 & 2 & 5 & 1 & 1 & - & - & - & - & - & - \\
\hline 6 & - & - & - & - & - & - & - & 1 & 2 & 1 & 1 & 1 \\
\hline
\end{tabular}

TABLE 4

NUMBER OF SEPTA IN AURELIA POLYPS AND NUMBER OF ARMS IN EPHYRAE PRODUCED BY THESE POLYPS

\begin{tabular}{|c|c|c|c|c|c|c|c|c|c|c|c|c|c|c|c|c|}
\hline \multirow[t]{2}{*}{ A } & \multirow[t]{2}{*}{ B } & \multirow[t]{2}{*}{ C } & \multicolumn{14}{|c|}{ Number of ephyrae with $n$ arms } \\
\hline & & & $n=2$ & $n=3$ & $n=4$ & $n=5$ & $n=6$ & $n=7$ & $n=8$ & $n=9$ & $n=10$ & $n=11$ & $n=12$ & $n=13$ & $n=14$ & Mean \\
\hline 2 & 10 & 65 & 1 & - & 47 & 5 & 11 & 1 & - & - & - & - & - & - & - & 4.4 \\
\hline 4 & 13 & 52 & - & - & - & - & - & 1 & 45 & 4 & 1 & - & 1 & - & - & 8.2 \\
\hline 6 & 11 & 29 & - & - & - & - & - & - & 2 & 2 & 16 & 1 & 8 & - & - & 10.7 \\
\hline 8 & 1 & 7 & - & - & - & - & - & - & - & - & - & - & - & 3 & 4 & 13.6 \\
\hline
\end{tabular}

A, Number of septa of parent polyps; B, Number of polyps analyzed; C, Number of ephyrae produced. 
the rhopalium, originates, while to the right and left a lobe develops made of two layers of ectodermal epithelium. Ephyrae display a tetraradial mouth opening with four mouth arms and four gastric filaments. When an ephyra starts to develop, the septa of the polyp regress. Eventually the peristomal pit (ectoderm) and the retractor muscle (ectoderm) (see Figure $3 \mathrm{~A}$ ) are enveloped
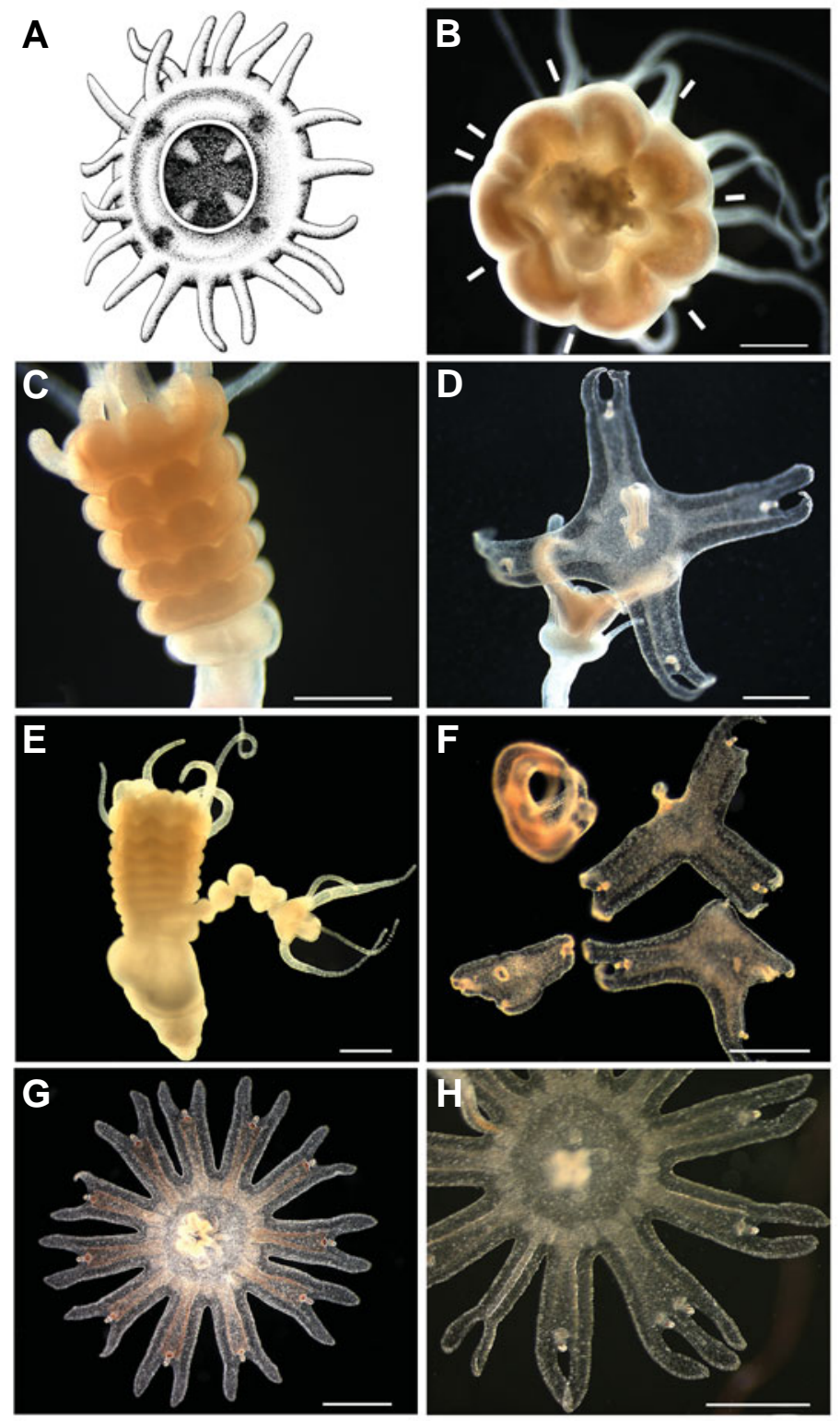

only by the remainder of the endoderm of a septum. When an ephyra is freed, this filament breaks and the remainder forms the gastric filaments. The rhopalium of an arm usually forms just above a (disappearing) septum (Figure 1C), whereas the adjacent rhopalium forms midway between two septa. Thus a polyp with four septa generally produces an ephyra with eight arms.

We found that the number of septa in a polyp determines the number of arms in the ephyrae produced. Polyps with two septa generally produce ephyrae with about four to six arms, two gastric filaments and two mouth arms (Figure 1D). From two to eight septa per polyp, the number of arms in the produced medusae increases in each step by about three (Table 4, Figure 2). We studied the strobilation of two specimens with only two septa that were asymmetrically arranged. One strobila produced three ephyrae, each with six arms. Above each septum an arm formed. In the smaller of the two gaps between the septa, one arm formed; in the larger one, three arms formed. Two ephyrae had two mouth arms, one ephyra had three. The other strobila produced two ephyrae, one with six arms and two mouth arms, the other with seven arms and four mouth arms. Obviously, no one-to-one relationship obtains between the number of septa, marginal arms and mouth arms. Rarely polyps without septa strobilate (Figure $1 \mathrm{E})$. We found the polyp's head to develop into ephyrae with three to five arms while the other anlagen developed into asymmetrically shaped ephyrae with one to three very small arms (Figure $1 \mathrm{~F})$. Because the polyp has no septa and no retractor, the ephyrae have no gastric filaments. Polyps with six septa usually produced ephyrae with six mouth arms, six gastric filaments and generally more than eight arms (Figure 1G). Four strobilae were studied in which two of the six septa were very close to each other. Two of these specimens produced in almost all ephyrae a rhopalium (and lateral lobes) just above each of these two septa and no rhopalia in between. However, in the last formed ephyra of one of the strobilae, which was somewhat smaller than the others, the

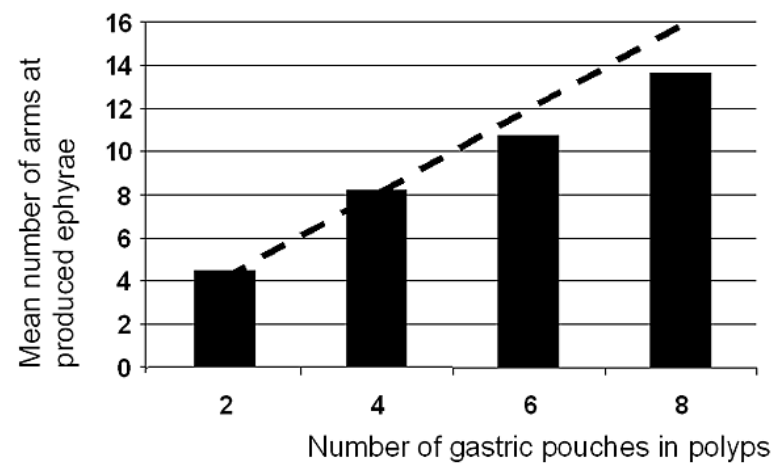

Fig. 1. Aurelia aurita. (A) Polyp, seen from above. The opened mouth allows the viewer to see the four septa (from Hein, 1900). (B) Polyp with eight septa, view from base (septa indicated by bars). (C) Strobila. From apical end to basal end, the polyp segments successively and each segment transforms into a medusa, termed ephyra at this stage. The basal part remains in the polyp phase. Note that at the site of the former septum, an ephyra rudiment develops a tip that eventually develops into a sense organ (rhopalium). (D) A just-liberated ephyra with 4 arms. The remainder (pale tissue) has developed polyp tentacles. At its apical end an ephyra with 2 arms has not yet been freed. (E) Parent polyp with four septa and a lateral polyp bud without septa both in the course of strobilation. (F) Ephyrae produced by the strobilating polyp bud shown in (E). (G) An ephyra with 11 arms. (H) An ephyra with malformations. Note that two rhopalia have formed so close to each other that the lobes between them remained small, whereas at a different position two small lobes have formed with no rhopalium in the center. Bar, $500 \mu \mathrm{m}$.

Fig. 2 . Relation of the number of septa in polyps to the number of arms of the resulting young medusae (ephyrae). The mean number of arms of ephyrae produced by given polyps is plotted against the number of gastric pouches the parent polyp had. The broken line indicates the number of arms expected if the number of septa of the parent animal exclusively determines the number of arms. Data obtained from Table 4. 


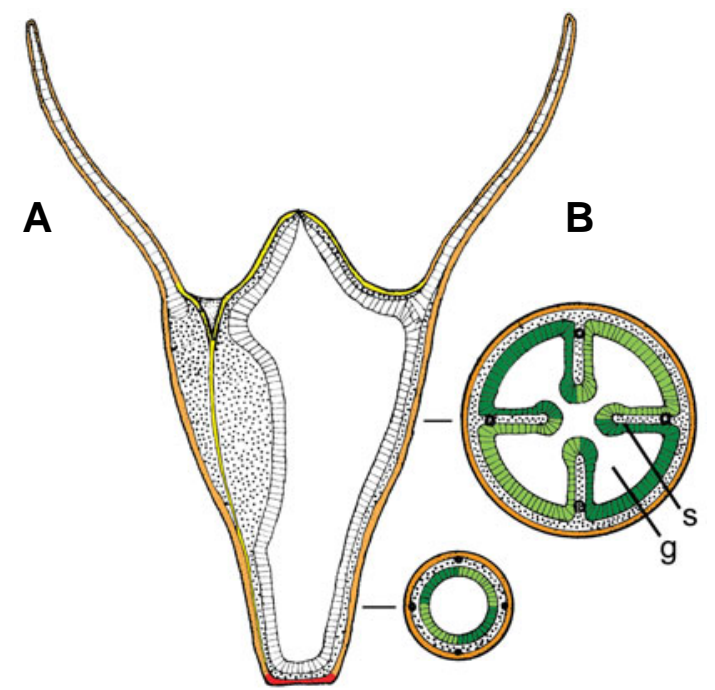

Fig. 3. Compartments in polyps of Aurelia. (A) Longitudinal section. (B) cross section at two positions, as indicated (s indicates a septum, $\mathrm{g}$ a gastric pouch) (basic drawing taken from Kästner 1984). Different compartments are indicated by different colors. Thus, oral disc ectoderm, yellow; body ectoderm, orange; basal disc ectoderm, red. Also, Endo A (endoderm), light green; Endo B (endoderm), dark green. For details see text.

respective arms were fused (Figure $1 \mathrm{H}$ ). In the two other specimens studied, the two septa were even closer to each other. In both cases all ephyrae produced a complete arm in the position between the two septa and none produced an arm above one of the adjacent septa. It appears that rhopalium formation is favored close to a septum but is not inevitably induced there.

The head of a strobilating polyp also eventually transforms into an ephyra. In this ephyra the tentacles regress and a rhopalium forms in close proximity to some of these tentacles (Friedemann 1902). In natural samples and under certain treatments various transition stages between rhopalia and tentacles have been observed, indicating that rhopalia and tentacles are homologue organs (Thiel 1963; Berking et al. 2005). Thus one can posit different types of tentacles, those which become replaced by rhopalia and those which regress in strobilation. In the course of polyp formation, tentacles form in a certain order (Friedemann 1902). In a 16-tentacle polyp, 8 tentacles are each replaced by a rhopalium and the others completely disappear. In rare cases we found that two rhopalia formed without a tentacle between them or with two tentacles between them. There certainly is no pattern hidden in the polyp in such a way that every second tentacle is predetermined to develop into a rhopalium. Rather, every tentacle appears to have a chance of developing into a rhopalium but the compounds that control the distance in rhopalia formation have a larger range than those which control the distance between tentacles.

Several conclusions can be drawn: (1) The number of arms and of mouth arms can be odd or even. (2) Small and large tetraradial polyps produce medusae with usually eight arms, but large polyps produce more ephyrae (Kroiher et al. 2000). (3) The more pouches a polyp has, the more arms are developed by the ephyrae that polyp produces. (4) Young ephyra anlagen produce tips almost midway between the oral and the aboral body end and each tip develops into a rhopalium. Rhopalium formation above a septum is particularly favored. The distance between rhopalia is almost twice as great as that between tentacles. (5) As observed by Hargitt (1905), arms may display malformations. Rhopalia can form so close to each other that the lobes between them are reduced. And lobes rarely form without a rhopalium structure in the center (Figure 1H).

\section{Discussion}

\section{The radial symmetry of polyps}

If septum formation were controlled by a patterning process that somehow directly starts septum formation, septa would form in even or odd numbers. Given that in Aurelia septa form in even numbers only, we suggest that the endoderm is longitudinally subdivided into two types of tissue. In the following discussion we call these types Endo A and Endo B, respectively (Figure 3). A septum forms where Endo A cells meet Endo B cells. Thus septa form in even numbers. The two types of endodermal tissues share
A

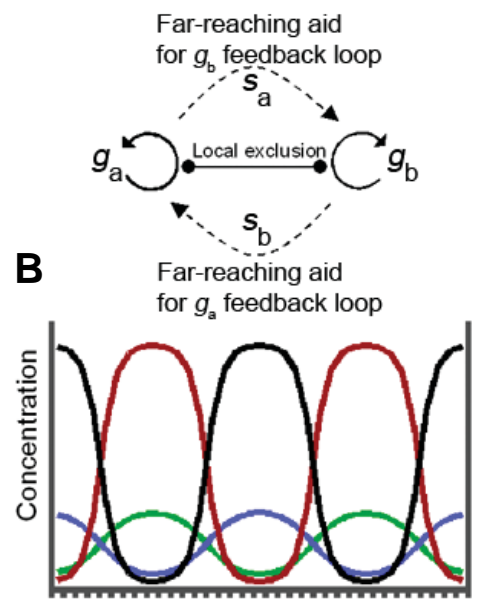

Position
C

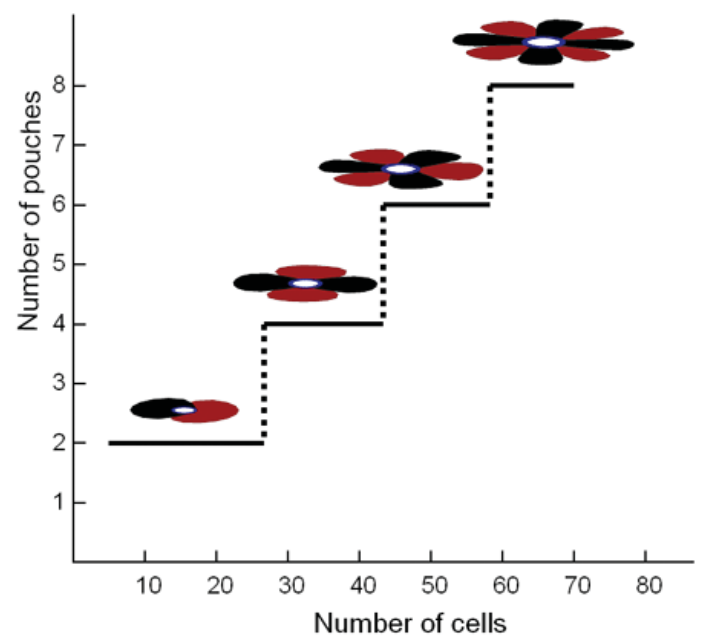

Fig. 4. Formation endodermal compartments by lateral activation of locally exclusive states. (A) Reaction scheme (see equations in Appendix). (B) Simulation: in a row of cells, the concentrations of $\mathrm{g}_{a}$ (black), $\mathrm{g}_{b}$ (red), $\mathrm{s}_{a}$ (blue) and $\mathrm{s}_{b}$ (green) are shown. A homogeneous distribution of $\mathrm{g}_{a}$ and $\mathrm{g}_{b}$ is unstable; two areas with either high $\mathrm{g}_{a}\left(\right.$ Endo A) or high $\mathrm{g}_{b}$ concentration (Endo B) form. Calculated with the following constants $\mathrm{D}_{\mathrm{g}}=0.02$, $D_{s}=0.1, D_{r}=0 . \alpha=1, \beta=0.04, \gamma=0.02, \varepsilon=0.01$, $\eta=0.03, \rho=0.001, d=1$. (C) With an increasing number of cells used for the simulation, the number of pouches increases. Simulation takes the form of a ring. The two colored areas show the local concentration of $\mathrm{g}_{a}$ and $\mathrm{g}_{b^{\prime}}$ respectively; $\mathrm{g}_{a}$ is shown in the foreground. The bars indicate the range within which a certain pattern develops. Note that only even numbers of pouches form. The technical basis of this simulation has been developed by Meinhardt (1995). 
A

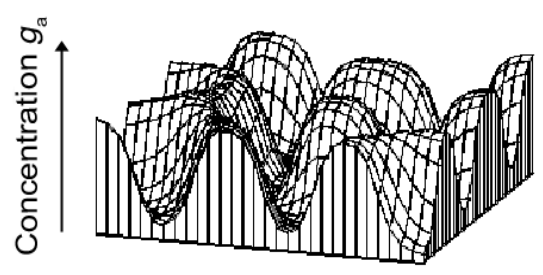

B

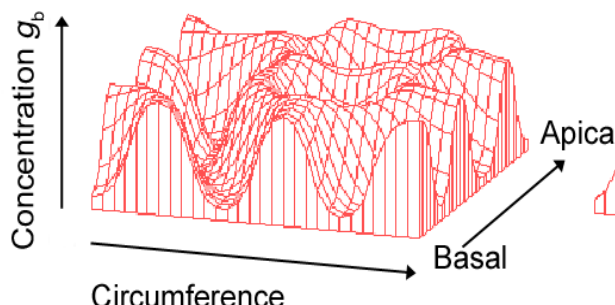

Circumference

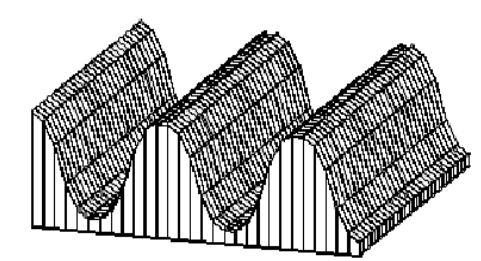

Positional information

Fig. 5. Formation of compartment in the form of stripes. (A) Simulation of the noted equations in two dimensions results in a subdivision of a field of cells in stripes in which either $\mathrm{g}_{a}$ or $\mathrm{g}_{b}$ is present at a high concentration. The field may represent an animal virtually sectioned from basal to apical. Field size: $\mathrm{x}=30, \mathrm{y}=30$ cells. Calculated with the following constants: $\mathrm{D}_{\mathrm{g}}=0.02, \mathrm{D}_{\mathrm{s}}=0.1, \mathrm{D}_{\mathrm{r}}=0, \alpha$ $=0.3, \beta=0.04, \gamma=0.08, \varepsilon=0.01, \eta=0.03, \rho=$ $0.001, d=1$. Starting at several random positions of elevated $\mathrm{g}_{a}$ concentration. (B) Same conditions but with a gradient of positional values from apical (maximal) $=0.01$ to basal with a change of $\mathrm{d}=1.1$ per cell. Starting at several random positions of elevated $\mathrm{g}_{a}$ concentration, equally sized stripes of Endo $A$ and of Endo $B$ cells finally form that run from the apical to the basal body end, causing the formation of gastric pouches separated by septa. The technical basis of this simulation has been developed by Meinhardt (1995).

properties with the tissues termed compartments in other organisms. Cells of a compartment form a continuous sheet. In general, following cell division in the descendants the state of the compartment is maintained. We found that polyps formed in asexual reproduction initially have gastric pouches of different diameter. A similar observation was made with respect to polyps produced in sexual reproduction (Goette 1887; Hein 1900). The initial uniform cylinder of endoderm may be assumed to consist of Endo A cells only. Within this cylinder some Endo A cells change their state, resulting in the formation of one or more small stripes of Endo B cells along the length axis. It thus appears that under certain conditions a group of cells can switch into a different state.

The cells of different compartments may look similar but can behave differently. In other words, their behavior is governed by mutually exclusive states. We suggest the endodermal compartments form by a mechanism that causes local mutual exclusion of the two states, combined with a mutual dependence of these two states, by far-reaching signals (see Appendix), as it has been proposed to explain the engrailed/wingless interaction in Drosophila (Meinhardt 1996). This mechanism is able to cause the formation of compartments in form of stripes. How many gastric pouches finally form in Aureliaappears not to be fixed genetically: In asexual reproduction, we found that the number of septa was not transmitted to the offspring. The initial number of cells in the circumference at the time of the onset of compartment formation may determine the number of pouches (see Appendix). However, the number of initially formed pouches later on largely determines the diameter of the adult polyp.

\section{The Radial Symmetry of Medusae}

In the course of medusa formation, septa disappear (for review, see Thiel 1966) and we did not detect a structure that is produced only in even numbers: The final number of rhopalia can be even or odd. The same holds for mouth arms and also for gonads in the adult medusa of Aurelia (repeatedly reported). Thus, it is unclear whether the subdivision of the endoderm into compartments persists.

However, the disappearing septa influence the patterning of an ephyra: In Aurelia, rhopalia form "above" a septum and also in the gap between two septa. The number formed-between zero and three-depends on the size of the gap. When the septa were very close to each other, a rhopalium formed, not above the right or the left septum but rather within the gap between the two septa. A similar patterning mechanism was observed with respect to stolon branching in Hydrozoa: Transient pressing of the stolon with a needle favors the formation of a lateral stolon bud. However, when the distance between two sites of pressing is less than a certain threshold distance, the branch does not originate at the site of pressing but rather in the middle between the two sites (Plickert 1980). Meinhardt (1982) explained this by assuming that the patterning process is controlled by two substances, an activator that stimulates its own production (self-enhancement) and an inhibitor that antagonizes activator production (lateral inhibition). The mechanism of rhopalia (and finally arm) formation thus appears well described by a mechanism of self-enhancement and lateral inhibition taking place in a belt of tissue in which the onset of self-enhancement is possible everywhere but is favored above a septum. With respect to the very first ephyra, which forms out of the polyp's "head," rhopalia formation appears to obey the same rules of distance control. However, there is one additional restriction: A rhopalium exclusively forms at the position of a tentacle.

\section{The Apical-Basal Organization of Medusae and Polyps}

In medusae of all cnidarian orders, an exumbrella and a subumbrella are distinguished. At sites where the respective ectodermal tissues meet, a double layer of ectoderm can form separated by a mesoglea, such as the lobes in ephyrae of Aurelia and the velum in hydromedusa. In medusae of Hydrozoa, the subumbrella ectoderm is argued to be a germ layer with properties of the mesoderm of bilaterians (Seipel and Schmid 2005). Only this tissue contains cells with cross-striated muscle fibers, as does the mesoderm of bilaterians. In ephyrae of Aurelia, too, such cells are found exclusively in the ectoderm of the subumbrella (Chuin 1930; Matsuno 1983; Chapman 1999). We suggest that the ectoderm of ephyrae is subdivided into-at least-two compartments. Right and left of a rhopalium forms a double lamella of ectoderm, of which the upper side is made by the exumbrella ectoderm and the lower side by subumbrella ectoderm. Rhopalia form at the border between the two compartments. Their formation may involve a "co-operation of compartments," as observed 
for instance in limb formation in vertebrates (Meinhardt 1982).

The question is whether ectodermal compartments already exist in polyps, that is, before the medusa stage (Figure 3). The best indicator of such prior existence would be a double lamella of ectoderm at the site of contact. As far as we know, this has not been found. A weak argument is that the ectoderm in the oral disc differs from that of the body column (and that of the basal disc). For instance, the musculature differs (Chapman 1974, 1999; Hentschel and Hündgen 1980; Pollmanns and Hündgen 1981; Matsuno 1983). Further, the subumbrella of the first ephyra formed in strobilation ranges exactly from the polyp's mouth to the polyp's ring of tentacles. Moreover, the oral disc formed from the tissue that remains in the polyp stage at the end of strobilation displays several features of a subumbrella of an ephyra, including mouth formation (Thiel 1938) and patterning of the tentacles (Thiel 1963). In addition, in polyps of Scyphozoa a peristomal pit forms where the two endodermal compartments meet. In Stauromedusae, a subgroup of Scyphozoa, ectodermal cells initially immigrate from the oral disc into the mesoglea between ectoderm and endoderm of the body column. This occurs exclusively at the site of septum formation. In a second step, the two endodermal layers of the respective septum surround the immigrants completely (Wietrzykowsky 1912). In several other species, including Aurelia, the ectodermal cells of the oral disc split the endodermal layer of a septum to form the peristomal pit and the muscle strands (Friedemann 1902). Because the ectoderm subdivides into compartments, a pit may form. The adhesion between ectodermal cells of the oral disc compartment to both Endo $A$ and Endo $B$ cells is stronger than the adhesion between Endo $A$ and $B$ cells. This may force single cells or the sheet of cells of the oral disc ectoderm to invaginate, almost reaching the basal plate (see Figure 3). The cells of the body ectoderm compartment appear not to have this adhesion property.

In summary, we propose that both the ectoderm and the endoderm are subdivided into compartments. The borders of the ectodermal and endodermal compartments are perpendicular to each other. The patterning of polyps and medusae including the positioning of tentacles and rhopalia and the size regulation of septa (see Appedix) is largely the result of an interaction between compartments.

\section{Patterning of polyps and medusae of other Cnidaria}

In general, Scyphozoa polyps produce four septa. Anthozoa produce many more; they produce septa in couples or pairs, indicating the existence of endodermal compartments (Berking, 2007). Many polyps of Hydrozoa and Cubozoa display a tetraradial symmetry at least in an early state of development (see Müller 1964) but they do not produce septa. It is thus unclear whether endodermal compartments exist in hydrozoan polyps. The finding of scyphozoan polyps without septa indicates that a subdivision of the endoderm into compartments is not necessary to produce a complete polyp including an oral disc with a mouth opening surrounded by a ring of tentacles. Of course, these polyps have no peristomal pits. They, therewith, look similar to those of Hydrozoa and Cubozoa which do not produce septa.

Hydrozoa medusae generally produce four radial canals. Rarely, medusae form with three or five even-spaced radial canals, respectively (for review, see Kühn 1914; confirmed by us with respect to Thecocodium quadratum, not shown). The even spac- ing indicates that the uneven number of radial canals does not result from secondary events like regression or branching of an existing channel. It is thus unclear whether endodermal compartments exist in hydrozoan medusae, but if they do they do not control the formation of the radial canals. The mechanism that controls the number of canals in Hydrozoa medusae - usually four - as well as the number of arms in ephyrae - usually eight - appears to be completely different from the one that controls the number of septa in Scyphozoa polyps, which is also usually four. Medusae of Cubozoa display a tetraradial symmetry (Werner 1975). Deviations from that symmetry are not known to us.

\section{Materials and Methods}

Polyps of Aurelia aurita (collected from the North Sea at Luc sur Mer, Normandy, France) were mass cultured in artificial seawater (1000 mosmol, $\mathrm{pH} 8.2,20^{\circ} \mathrm{C}$ ). If not otherwise stated, throughout an experiment the polyps were kept separately in dishes with $1.0 \mathrm{~mL}$ of seawater at $20^{\circ} \mathrm{C}$. The polyps were not fed during the experiments except for the experiment leading to Table 2. In this experiment the animals were fed three times a week and kept in groups at a density of about 1 polyp per $\mathrm{mL}$. Strobilation was induced in a mass culture by subjecting the animals to $12^{\circ} \mathrm{C}$ for three weeks (Kroiher et al. 2000).

\section{Acknowledgements}

The technical basis of the computer simulation here presented is the excellent program H. Meinhardt (1995) developed for calculating patterns on sea shells.

\section{References}

BERKING, S. (2003). A model for budding in Hydra: pattern formation in concentric rings. J. Theor. Biol. 222, 37-52.

BERKING, S. (2006). Principles of branch formation and branch patterning in Hydrozoa. Int. J. Dev. Biol. 50, 123-134.

BERKING, S. (2007). Generartion of bilateral symmetry in Anthozoa: a model. J. Theor. Press (in press).

BERKING, S., CZECH, N., GERHARZ, M., HERRMANN, K., HOFFMANN, U., RAIFER, H., SEKUL, G., SIEFKER, B., SOMMEREI, A. and VEDDER, F. (2005). A newly discovered oxidant defence system and its involvement in the development of Aurelia aurita (Scyphozoa, Cnidaria): reactive oxygen species and elemental iodine control medusa formation. Int. J. Dev. Biol. 49, 969-976.

CHAPMAN, D. M. (1974). Cnidarian histology. In: Coelenterate biology (ed. L. Muscatine and H. M. Lenhoff), pp. 1-92. Academic Press, New York and London.

CHAPMAN, D. M. (1999). Microanatomy of the bell rim of Aurelia aurita (Cnidaria, Scyphozoa). Can. J. Zool. 77, 34-46.

CHUIN, T.T., (1930). Le cycle évolutif du scyphistome de Chrysaora: étude histophysiologique. Trav. stn. biol. Roscoff, publiés par Charles Pérez, Fasc. 8, 1-179. Presses Univ. De France, Paris.

FRIEDEMANN, O. (1902). Untersuchungen über die postembryonale Entwicklung von Aurelia aurita. Z. wiss. Zool. 71, 227-267.

GIERER, A. and MEINHARDT, H. (1972). A theory of biological pattern formation. Kybernetik 12, 30-39.

GOETTE, A. (1887). Entwicklungsgeschichte der Aurelia aurita und Cotylorhiza tuberculata. Verlag von Leopold Voss, Hamburg und Leipzig.

HAND, C. (1966). On the evolution of the Actiniaria. In: The cnidaria and their evolution (ed. W. J. Rees). Academic Press, London.

HARGITT, C. W. (1905). Variations among Scyphomedusae. J. Exp. Zoöl. 2, 547584.

HEIN, W. (1900). Untersuchungen über die Entwicklung von Aurelia aurita. Z. wiss. Zool. 67, 401-438. 
HENTSCHEL, J. and HÜNDGEN, M. (1980). The morphology and ultrastructure of the scyphistoma of Aurelia aurita (Scyphozoa, Semaeostomae). Zool. Jb. Anat. 104, 295-316.

KÄSTNER, A. (1984). Lehrbuch der speziellen Zoologie. Gustav Fischer, Stuttgart.

KROIHER, M., SIEFKER, B. and BERKING, S. (2000). Induction of segmentation in polyps of Aurelia aurita (Cnidaria, Scyphozoa) into medusae and formation of mirror-image medusa anlagen. Int. J. Dev. Blol. 44, 485-490.

KÜHN, A. (1914). Entwicklungsgeschichte und Verwandschaftsbeziehungen der Hydrozoen. 1. Teil: Die Hydroiden. Erg. Fortschr. Zool. 4, 1-284.

MATSUNO, A. (1983). An electron microscopic study on the development of the cross-striated muscles in ephyrae of Aurelia aurita. Zool. Mag., Tokyo 92, 416522.

MEINHARDT, H. (1982). Models of biological pattern formation. Academic Press, London.

MEINHARDT, H. (1993). A model of biological pattern formation of hypostome tentacles and foot in Hydra: how to form structures close to each other, how to form them at a distance. Dev. Biol. 157, 321-333.

MEINHARDT, H. (1995). The algorithmic beauty of sea shells. Springer-Verlag, Berlin, Heidelberg, New York.

MEINHARDT, H (1996). Models of biological pattern formation: common mechanism in plant and animal development. Int. J. Dev. Biol. 40, 123-134.

MEINHARDT, H. and GIERER, A. (1980). Generation and regeneration of sequences during morphogenesis. J. theor. Biol. 85, 321-333.

MÜLLER, W.A. (1964). Experimentelle Untersuchungen über Stockentwicklung, Polypendifferenzierung und Sexualchimären bei Hydractinia echinata. Wilhelm Roux' Archiv für Entwicklungsmechanik 155, 181-268.

PLICKERT, G. (1980). Mechanically induced stolon branching in Eirene viridula (Thecata, Campanulinidae). In: Developmental and cellular biology of co elenterates(ed. P. Tardent and R. Tardent), pp. 185-190. Elsevier, Amsterdam.

POLLMANNS, D. and HÜNDGEN, M. (1981). Licht- und Elektronenmikroskopische
Untersuchung der Rhopalien von Aurelia aurita (Scyphozoa, Semaeostomae). A light and electron microscopic study of the rhopalia of Aurelia aurita(Scyphozoa, Semaeostomae). Zool. Jb. Anat. 105, 508-525.

REES, W. J. (1966). The evolution of the Hydrozoa. In: The cnidaria and their evolution (ed. W. J. Rees). Academic Press, London.

SEIPEL, K. and SCHMID, V. (2005). Evolution of striated muscle: jellyfish and the origin of triploblasty. Dev. Biol. 282, 14-26.

SHERRATT, J. A., MAINI, P. K., JÄGER, W. and MÜLLER, W. A. (1995). A receptor based model for pattern formation in Hydra. Forma 19, 77-95.

SHOJI, H., MOCHIZUKI, A., IWASA, Y., HIRATA, M., WATANABE, T., HIOKI, S. and KONDO, S. (2003). Origin of directionality in the fish stripe pattern. Dev Dynamics 226, 627-633.

THIEL, M. E. (1938). Scyphomedusae. Bronn's KI. Ordn. Tierreichs 2, 1-1308.

THIEL, H. (1963). Untersuchungen über die Entstehung abnormer Scyphistomae, Strobilae und Ephyrae von Aurelia auritaLAM. und ihre theoretische Bedeutung. Zool. Jb. Anat. 81, 311-358.

THIEL, H. (1966). The evolution of scyphozoa. A review. In: The cnidaria and their evolution (ed. W. J. Rees), pp. 77-117. Academic Press, London.

WERNER, B. (1975). Bau und Lebengeschichte des Polypen von Tripedalia cystophora (Cubozoa, class nov. Carybdeidae) und seine Bedeutung für die Evolution der Cnidaria. Helg. wiss. Meeresunters. 27, 461-504.

WIETRZYKOWSKY, W. (1912). Recherches sur le dévelopment des Lucernaires. Arch. Zool. Exp. gén. 5, 1-95.

WOLPERT, L. (1969). Positional information and the spatial pattern of cellular differentiation. J. Theor. Biol. 25, 1-47.

ZERETZKE, S. and BERKING, S. (2002). In the multiheaded strain mh 1 of Hydra magnipapillata the ectodermal epithelial cells are responsible for the formation of additional heads and the endodermal epithelial cells for the reduced ability to regenerate a foot. Develop. Growth and Differ. 44, 85-93.

Received: 11th August 2006 Reviewed by Referees: 26th September 2006

Modified by Authors and Accepted for Publication: 9th November 2006 Published Online: 27th April 2007

\section{Appendix}

With respect to polyps of Hydrozoa, it is assumed that pattern formation is controlled by a reaction-diffusion system that cause the formation of the various structures via a tissue property termed positional value or source. The positional values form a gradient from the oral end (maximal value / highest density of sources) to the basal end (Wolpert 1969; Gierer and Meinhardt 1972; Meinhardt 1993; Sherratt et al. 1995; Berking 2003, 2006). Recently, with respect to Hydraindications for a differential role of ectoderm and endoderm in the control of pattern formation have been found (Zeretzke and Berking 2002), but until now models have not been adjusted to account for these results. The various models may allow us to understand the subdivision of the ectoderm into compartments but are inappropriate to explain the formation of endodermal compartments.

The development of pairs of endodermal compartments may be controlled by a mechanism which was termed «lateral activation» (Meinhardt and Gierer1980; Meinhardt 1982). We slightly altered the original equations to get the desired properties. The activators $g_{\mathrm{a}}$ and $g_{\mathrm{b}}$ are the (autocatalytic) substances required for selfstabilization. The local mutual exclusion of the two states Endo $A$ and Endo B is brought about by a common repressor (see Equation 3). The diffusible substances $s_{a}$ and $s_{b}$ provide far-reaching help from one feedback system to the other. We propose that the gradient of positional values (denoted by $d$ in Equations 4 and 5) influences production of the substances $s_{\mathrm{a}}$ and $s_{\mathrm{b}}$. When the number of cells within the circumference of a larva is small, all cells express $g_{\mathrm{a}}$ and $g_{\mathrm{b}}$ (not shown). When the range of the diffusible compounds becomes smaller than the size of the field of cells, the uniform state becomes unstable and some produce only $g_{\mathrm{a}}$ while the others produce only $g_{\mathrm{b}}$ and so on (Figure 4).

Computer simulation in two dimensions results in the apparent formation of equally sized stripes if the gradient of positional values (d) influences the production of the substances $s_{\mathrm{a}}$ and $s_{\mathrm{b}}$ (see Equations 4 and 5, Figure 5). Stripes form parallel to the orientation 
of the gradient. The simulation was started by a random fluctuation of the $g_{\mathrm{a}}$ concentration in the field of cells. The parameter $d$ was introduced in equations 4 and 5 in such a way that stripes start to form where the positional value is high. Without a gradient of positional values stripes form in a random orientation. These stripes are often short and branched (Figure 5). Shoji et al. (2003) found by computational analysis that a diffusion anisotropy is effective at specifying the direction of stripes formed by a reactiondiffusion system. With respect to Cnidaria we argue the graded distribution of a quantitative cell parameter - the positional value to be a primary element of the pattern forming system. We thus propose this parameter and not a diffusion anisotropy to control stripe formation in Aurelia.

$$
\begin{aligned}
& \frac{\partial g_{a}}{\partial t}=\frac{\alpha s_{b} g_{a}{ }^{2}}{r}-\beta g_{a}+D_{g} \frac{\partial^{2} g_{a}}{\partial x^{2}}+\rho \\
& \frac{\partial g_{b}}{\partial t}=\frac{\alpha s_{a} g_{b}{ }^{2}}{r}-\beta g_{b}+D_{g} \frac{\partial^{2} g_{b}}{\partial x^{2}}+\rho \\
& \frac{\partial r}{\partial t}=\alpha s_{a} g_{b}{ }^{2}+\alpha s_{b} g_{a}{ }^{2}-\gamma r \\
& \frac{\partial s_{a}}{\partial t}=\varepsilon \frac{g_{a}}{d}-\eta s_{a}+D_{s a} \frac{\partial^{2} s_{a}}{\partial x^{2}} \\
& \frac{\partial s_{b}}{\partial t}=\varepsilon \frac{g_{b}}{d}-\eta s_{b}+D_{s b} \frac{\partial^{2} s_{a}}{\partial x^{2}}
\end{aligned}
$$

The shape of a septum may depend on influences of the ectoderm: The contact between Endo A and Endo $B$ cells is a necessary condition for septum formation, but the absence of septal tissue in Aurelia polyps at both the oral body end and the aboral end indicates that this condition is not sufficient. We suspect that ectodermal cells generate a diffusible substance where the body ectoderm compartment and the oral disc ectoderm compartment meet. Such an interaction has been termed "co-operation of compartments" (Meinhardt 1982). When endodermal cells need this substance for proliferation and survival the septa grow in form of triangles with maximal height at the position where the body ectoderm compartment and the oral disc ectoderm compartment meet, as observed. Further, the size of the gastric pouch is maximal at that very site, as observed (see Figure 3). The interaction of the compartments shapes the gastric pouch into a rhombus and therefore the scyphopolyp (from the Greek word scyph, a cup) develops a cup shape. In Aurelia strong proliferation of endodermal cells in the septal periphery was observed at the site where the ectodermal and the endodermal compartments meet (Friedemann, 1902).

Taken together, it appears that the mutual exclusion of the two cell states combined with a mutual dependence of the same states is basic for germ layer formation. On the one hand, a cell is either ectoderm or endoderm; these two states mutually exclude each other. On the other hand, ectoderm and endoderm depend on each other in formation and survival functions. The cells of the two germ layers develop different adhesion properties, which causes them to separate. The altered adhesion properties may at least facilitate gastrulation movements.

\section{Related Int. J. Dev. Biol. articles}

Mesodermal anatomies in cnidarian polyps and medusae. Katja Seipe/ and Volker Schmid. Int. J. Dev. Biol. (2006) 50: 589-599

Morphomechanical programming of morphogenesis in Cnidarian embryos. Yulia A. Kraus. Int. J. Dev. Biol. (2006) 50: 267-275

Metamorphosis of Hydractinia echinata (Cnidaria) is caspase-dependent. Stefanie Seipp, Karola Wittig, Beate Stiening, Angelika Böttger and Thomas Leitz. Int. J. Dev. Biol. (2006) 50: 63-70

Spatial patterns formed by chemotactic bacteria Escherichia coli. Andrey A. Polezhaev, Ruslan A. Pashkov, Alexey I. Lobanov and lgor B. Petrov. Int. J. Dev. Biol. (2006) 50: 309-314

Integument pattern formation involves genetic and epigenetic controls: feather arrays simulated by digital hormone models. Ting-Xin Jiang, Randall B Widelitz, Wei-Min Shen, Peter Will, Da-Yu Wu, Chih-Min Lin, Han-Sung Jung and Cheng-Ming Chuong. Int. J. Dev. Biol. (2004) 48: 117-135

Patterning a multi-headed mutant in Hydractinia: enhancement of head formation and its phenotypic normalization. Werner A Müller, Regina Teo and Frank Möhrlen. Int. J. Dev. Biol. (2004) 48: 9-15

A moving wave patterns the cone photoreceptor mosaic array in the zebrafish retina. Pamela $A$. Raymond and Linda K. Barthel. Int. J. Dev. Biol. (2004) 48: 935-945.

Segmentation: mono- or polyphyletic? Elaine C Seaver. Int. J. Dev. Biol. (2003) 47: 583-595 